\title{
ANALISIS RISIKO BAHAYA PADA PEKERJA DI TEMPAT PENAMPUNGAN SAMPAH TERPADU REDUCE REUSE RECYCLE (TPST 3R) MULYOAGUNG BERSATU DAU KABUPATEN MALANG
}

\author{
Lucky Radita Alma, Nurnaningsih Herya Ulfah, Yudhi Utomo, Afifah, Uciatul \\ Adawiyah, Wakhi Datul Nur Kholifah, ling Merillarosa \\ Universitas Negeri Malang \\ lucky.radita.fik@um.ac.id
}

\begin{abstract}
Abstrak
Tempat penampungan sampah terpadu reduce reuse recycle (TPST 3R) Mulyoagung Bersatu Dau merupakan salah satu diantara TPS yang ada di Kabupaten Malang. Setiap harinya TPS tersebut menampung berbagai macam sampah dari masyarakat di sekitar Kecamatan Dau sebelum diangkut ke TPA. Kegiatan pengelolaan sampah yang dilakukan pekeja, pengumpulan dan pemilahan sampah, mempunyai potensi terjadinya kecelakaan dan penyakit akibat kerja terlebih pelaksanaan K3 belum dilakukan sesuai standar. Tujuan penelitian ini untuk mengetahui gambaran risiko bahaya pada pekerja di TPST 3R Mulyoagung Bersatu Kecamatan Dau Kabupaten Malang. Penelitian ini merupakan penelitian diskriptif observasiional. Responden penelitian sebanyak 36 orang. Hasil dari penelitian ini, sebanyak 58\% pekerja menyatakan bahaya yang "Sering" terjadi pada pekerja adalah tergores dan terjatuh. Sebesar 58\% pekerja menyatakan "Sering" mengalami diare dan gangguan gastroinstestinal. Diperlukan upaya pencegahan dan penanggulangan terhadap bahaya ditempat kerja misalkan dengan praktik kerja yang aman, penggunaan Alat Pelindung Diri (APD) yang sesuai standart dan praktik higiene perorangan untuk mencegah terjadinya penularan penyakit bawaan sampah.
\end{abstract}

Kata kunci: alat pelindung diri (APD), keselamatan dan kesehatan kerja (K3)

\begin{abstract}
Integrated waste bin of Reduce Reuse Recycle (TPST 3R) Mulyoagung Bersatu Dau is one of the TPS in Malang Regency. Every day the TPST carry out various kinds of garbage from the community around Dau District before being transported to the final rubbish dump. The waste management activities carried out by the workers, have the potential for accidents and diseases caused by work, especially the implementation of health and safety has not been done according to standards. The purpose of this study was to determine the description of hazard risks to workers in TPST 3R Mulyoagung Bersatu District of Dau Malang Regency. This research was a descriptive observational study. Research respondents were 36 people. The results of this study, as many as $58 \%$ of workers stated that the danger that "often" occurs to workers is scratched and dropped. 58\% of workers stated "often" had diarrhea and gastrointestinal disorders. Efforts to prevent and control hazards in the workplace are needed, for example with safe work practices, the use of Personal Protective Equipment (PPE) in accordance with standards and personal hygiene practices to prevent the transmission of congenital rubbish.
\end{abstract}

Keywords: personal protective equipment (PPE), occupational safety and health(OSH)

\section{PENDAHULUAN}

Berdasarkan data dari Dinas Lingkungan Hidup, jumlah produksi sampah di Kabupaten Malang sebesar 1004,86 ton per hari, berarti dalam satu bulan ada sekitar 30.000 ton sampah yang terkumpul di TPA Talangagung. Tempat penampungan sampah (TPS) atau disebut juga transfer dipo merupakan tempat 
penampungan sebelum sampah diangkut ke tempat daur ulang, pengolahan, dan/atau tempat pengolahan sampah terpadu. Pengelolaan sampah di TPS yang tidak aman dapat menimbulkan dampak negatif bagi pekerja sampah berupa kecelakaan atau cedera dan penyakit akibat kontak langsung antar pekerja dengan sampah dan atau kontak dengan vektor pembawa penyakit yang berkembangbiak pada sampah. Untuk melindungi dan menjamin keselamatan setiap tenaga kerja dan orang lain di tempat kerja, menciptakan tempat kerja yang aman, nyaman dan efisien untuk mendorong produktivitas produktivitas maka perlu diadakan pelaksanaan K3 (Kesehatan dan Keselamatan Kerja).

Tempat Penampungan Sampah Terpadu Reduce Reuse Recycling (TPST 3R) Mulyoagung Bersatu merupakan salah satu diantara TPS yang ada di Kabupaten Malang yang terletak di Kecamatan Dau. Setiap harinya TPST tersebut menampung berbagai macam sampah dari masyarakat di sekitar Kecamatan Lowokwaru sebelum diangkut ke TPA. Kegiatan pengelolaan sampah yang dilakukan oleh para pekerja mempunyai potensi terjadinya kecelakaan dan penyakit akibat kerja terlebih jika pelaksanaan program keselamatan dan kesehatan kerja (K3) belum dilakukan sesuai standar. Upaya identifikasi potensi bahaya perlu dilakukan sehingga dapat diketahui potensi bahaya yang ada dan penyebabnya, selanjutnya dapat dilakukan tindakan untuk mengatasi dan mencegah terjadinya potensi bahaya di tempat kerja tersebut. Salah satu upaya yang dapat dilakukan untuk mengetahui potensi bahaya adalah dengan melakukan hazard analysis atau analisis potensi bahaya.

\section{METODE}

Penelitian ini merupakan penelitian desktiptif observasional yaitu untuk mengetahui gambaran risiko bahaya di tempat kerja. Jumlah sampel yang diamati sebanyak 36 orang yang merupakan pengelola di TPST 3R Mulyoagung Bersatu, yang terdiri dari petugas administrasi, pemungut, pemilah, dan mengangkut sampah. Pengambilan data dilakukan dengan membagikan kuesiner berisi pertanyaan tertutup dan dengan observasi lagsung terhadap kondisi lingkungan dan kegiatan pekerja dalam bekerja. Analisis dilakukan secara deskriptif yang disajikan menggunakan tabel distribusi frekuensi dan narasi. Tahapan analisis potensi bahaya yang dilakukan menggunakan pendekatan Hazard Identification dan Risk Assesment dari Occupational Safety and Health Administration (OSHA) yaitu sebagai berikut pengembangan rencana (Develop a Plant), identifikasi adanya bahaya (Identify Hazard), menilai risiko bahaya (Assess the Risk), membuat perubahan (Make the Change), dan mengecek perubahan (Checking the Changes) (Puspitasari, 2010).

\section{HASIL DAN PEMBAHASAN}

Tabel 1. Safety Psychology

\begin{tabular}{|c|c|c|c|c|c|}
\hline Item & STS & TS & N & S & SS \\
\hline $\begin{array}{l}\text { Perusahaan mengadakan pelatihan } \\
\text { Kesehatan dan Keselamat Kerja (K3) }\end{array}$ & $0 \%$ & $10 \%$ & $6 \%$ & $45 \%$ & $22 \%$ \\
\hline
\end{tabular}




\begin{tabular}{|l|c|c|c|c|c|}
\hline $\begin{array}{l}\text { untuk pelaksanaan pekerjaan yang } \\
\text { berpotensi bahaya }\end{array}$ & $0 \%$ & $19 \%$ & $8 \%$ & $59 \%$ & $14 \%$ \\
\hline $\begin{array}{l}\text { Perusahaan telah melakukan sosialisasi } \\
\text { tentang program Kesehatan dan } \\
\text { Keselamatan Kerja }\end{array}$ & $0 \%$ & $25 \%$ & $0 \%$ & $19 \%$ & $56 \%$ \\
\hline $\begin{array}{l}\text { Perusahaan memiliki motivasi yang } \\
\text { baik untuk melaksanakan K3 }\end{array}$ & & & & \\
\hline
\end{tabular}

Keterangan*: STS = sangat tidak setuju, $\mathrm{TS}=$ tidak setuju, $\mathrm{N}=$ netral, $\mathrm{S}=$ setuju, $\mathrm{SS}=$ sangat setuju

Berdasarkan Tabel 1, sebanyak 45\% pekerja menyatakan "Setuju" apabila perusahaan mengadakan pelatihan Kesehatan dan Keselamatan Kerja (K3) untuk pelaksanaan pekerjaan yang berpotensi bahaya. Lebih dari separuh pekerja atau sebsar 59\% menyatakan "Setuju" apabila perusahaan melakukan sosialisasi tentang Program Kesehatan dan Keselamatan Kerja. Dan sebanyak 56\% pekerja mengatakan "Sangat Setuju" apabila perusahaan memiliki motivasi yang baik untuk melaksanakan K3.

Salah satu tindakan pencegahan dan pengendalian bahaya dapat dilakukan dengan penyelenggaraan pelatihan. Tujuan penyelenggaran pelatihan yakni untuk meningkatkan kompetensi tenaga kerja, juga untuk meningkatkan kesadaran dan pengetahuan pekerja. Pelatihan K3 bertujuan agar pekerja mampu memahami dan mempraktikkan tindakan keselamatan dan kesehatan kerja, mengidentifikasi potensi bahaya di tempat kerja, melakukan tindakan pencegahan terjadinya kecelakaan kerja, memakai alat pelindung diri sesuai kebutuhan, serta menyusun program pengendalian keselamatan dan kesehatan kerja di tempat kerja (Hargiyarto, 2010). Pelatihan K3 seyogyanya dilakukan secara berkala dan berkesinambungan sehingga pesan yang disampaikan akan diingat dalam jangka waktu yang tidak sebentar dengan harapannya akan tumbuh kesadaran pekerja untuk mempraktikkan hasil pelatihan yang dilakukan (Putri, 2013).

Tabel 2. Peluang Terjadinya Bahaya

\begin{tabular}{|c|c|c|c|}
\hline \multirow[t]{2}{*}{ Item } & \multicolumn{3}{|c|}{ Jawaban } \\
\hline & $\mathbf{J}$ & SR & SL \\
\hline \multicolumn{4}{|l|}{ Peluang Terjadinya Kecelakaan } \\
\hline Tergores & $20 \%$ & $58 \%$ & $22 \%$ \\
\hline Tertusuk benda tajam & $25 \%$ & $47 \%$ & $28 \%$ \\
\hline Terpelintir & $50 \%$ & $47 \%$ & $3 \%$ \\
\hline Terpeleset & $47 \%$ & $50 \%$ & $3 \%$ \\
\hline Jatuh & $39 \%$ & $58 \%$ & $3 \%$ \\
\hline \multicolumn{4}{|l|}{ Peluang Terjadinya Penyakit } \\
\hline Diare & $20 \%$ & $58 \%$ & $22 \%$ \\
\hline Penyakit Kulit (gatal-gatal) & $25 \%$ & $47 \%$ & $28 \%$ \\
\hline Penyakit pernafasan & $50 \%$ & $47 \%$ & $3 \%$ \\
\hline Kardiovaskuler & $47 \%$ & $50 \%$ & $3 \%$ \\
\hline Gastroinstetinal & $39 \%$ & $58 \%$ & $3 \%$ \\
\hline Muskuloskeletal disorder & $6 \%$ & $22 \%$ & $0 \%$ \\
\hline
\end{tabular}

Keterangan: J = jarang, $\mathrm{SR}=$ sering, $\mathrm{SL}=$ selalu

Tabel 2 dapat diketahui bawa peluang terjadinya kecelakaan yang sering diamali oleh pekerja yaitu tergores dan jatuh, masing masing sebesar 58\%, terpeleset $(50 \%)$ dan tertusuk benda tajam (47\%). Sedangkan peluang terjadinya 
penyakit yang paling sering dialami pekerja sebagian besar yaitu diare dan gastrointestinal (58\%). Risiko terjadinya kecelakaan berupa tergores dan tertusuk dimungkinkan terjadi karena sampah yang dikelola oleh pekerja mengandung benda tajam, seperti paku, tusuk sate dan pecahan kaca sehingga apabila pekerja tidak hati dan tidak menggunakan alat pelindung diri maka sangat dimungkinkan tergores atau tertusuk benda-benda tersebut. Sikap kerja yang tidak sesuai postur tubuh dan lingkungan yang tidak aman berisiko menyebabkan pekerja mengalami terjatuh dan atau terpeleset. Kondisi lantai yang berair pada zona kedatangan sampah

Berdasarkan hasil tersebut yang menjadi dasar hukum dari alat pelindung diri ini adalah Undang-Undang Nomor 1 Tahun 1970 Bab IX Pasal 13 tentang Kewajiban Bila Memasuki Tempat kerja yang berbunyi: "Barangsiapa akan memasuki sesuatu tempat kerja, diwajibkan mentaati semua petunjuk keselamatan kerja dan memakai alat-alat perlindungan diri yang diwajibkan. ”. Alat pelindung diri adalah kelengkapan yang wajib digunakan saat bekerja sesuai kebutuhan untuk menjaga keselamatan pekerja itu sendiri dan orang di sekelilingnya. Alat pelindung diri berupa sarung tangan dapat berfungsi sebagai pelindung tangan pada saat bekerja di tempat atau situasi yang dapat mengakibatkan cedera tangan, seperti tertusuk dan tergores benda tumpul dan tajam (Kusuma \& Darmastuti, 2010, hal. 49). Jenis risiko terpeleset dapat dicegah dengan pemakaian sepatu anti selip saat bekerja (Ihsan, Edwin and Octavianus Irawan, 2016). Pencegahan terhadap penyakit bawaan sampah seperti gangguan gastrointestinal dan diare dapat dilakukan dengan melakukan higiene perseorangan serta pemakaian alat pelindung diri. Praktik hygiene dapat dilakukan dengan melakukan cuci tangan dengan sabun serta mandi setelah beraktivitas mengelola sampah guna menghilangkan kuman penyakit yang menempel pada tubuh. Hal ini dapat memutuskan mata rantai penularan penyakit, terlebih setelah menyentuh sampah pekerja langsung mengkonsumsi makanan. Pemakaian alat pelindung diri mencegah penularan penyakit bawaan sampah dimana alat pelindung diri berperan sebagai barrier tubuh ketika kontak dengan sampah, sehingga tubuh tidak bersentuhan langsung dengan sampah pada saat proses pengelolaan sampah (Adnani, 2010).

\section{KESIMPULAN DAN SARAN}

Dari hasil pembahasan diatas dapat disimpulkan bahwa para pekerja di Tempat Pembuangan Sampah Terpadu (TPST) 3R sebagian besar pekerja (59\%) menginginkan adanya sosialisasi Kesehatan dan Keselamatan Kerja. Karena pelatihan K3 sendiri masih sangat dibutuhkan untuk para pekerja guna meminimalisir kecelakaan dan penyakit akibat kerja. Masih banyaknya kejadiankejadian bahaya yang terjadi di TPST 3R Mulyoagung Terpadu pada saat mengumpulkan, memilah, dan mengangkut sampah maka sangat penting adanya penyediaan dan penggunaan Alat Pelindung Diri (APD) untuk para pekerja. Selain 
itu pentingnya analisis kondisi lingkungan yang baik dapat meningkatkan kinerja bagi pekerja. Setelah dilakukannya sosialisasi K3 pemberian APD, dan tes kesehatan kepada para pekerja diharapkan dapat mengurangi kecelakaan dan penyakit akibat kerja di TPST 3R Mulyoagung Terpadu.

\section{Ucapan Terimakasih}

Sehubungan dengan terbitnya artikel ini, kami segenap Tim Penyusun mengucapkan terimakasih atas pihak PNBP UM yang memberikan dukungan terhadap terlaksanakannya pengabdian ini, pihak LP2M Universitas Negeri Malang yang membantu terhadap pelaksanaan pengabdian ini dan mitra yakni TPST 3R Mulyoagung Terpadu Kecamatan Dau Kabupaten Malang, serta seluruh masyarakat yang turut berpartisipasi.

\section{DAFTAR RUJUKAN}

Adnani, H. (2010) 'Perilaku Petugas Pengumpul Sampah untuk Melindungi Dirinya dari Penyakit Bawaan Sampah di Wilayah Patangpuluhan Yogyakarta Tahun 2009', Kesmas, 4(3), pp. 144-239.

Buchari, 2007. Manajemen Kesehatan Kerja dan Alat Pelindung Diri.

Hargiyarto, P. (2010) 'Pelatihan Keselamatan dan Kesehatan Kerja serta Pencegahan Kecelakaan Kerja'.

Ihsan, T., Edwin, T. and Octavianus Irawan, R. (2016) 'Analisis Risiko K3 Dengan Metode Hirarc Pada Area Produksi Pt Cahaya Murni Andalas Permai', Jurnal Kesehatan Masyarakat Andalas, 10(2), pp. 179-185. doi: 10.24893/jkma.v10i2.204.

K Saefulla, E. S. (2005). Pengantar Manajemen Edisi Pertama. Jakarta: PT. Fajar Interpratama Mandiri.

Kusuma, I. J., \& Darmastuti, I. (2010). Pelaksanaan Program Keselamatan Dan Kesehatan Kerja Karyawan Pt. Bitratex Industries Semarang. Jurnal Studi Manajemen \& Organisasi, VII, 48-49.

Lestari, T. and Trisyulianti, E. (2007) 'Hubungan Keselamatan dan Kesehatan (K3) dengan Produktivitas Kerja Karyawan (Studi Kasus: Bagian Pengolahan PTPN VIII Gunung Mas, Bogor)'.

Prihantoro, A. (2012). Peningkatan Kinerja Sumber Daya Manusia Melalui Motivasi, Disiplin, Lingkungan Kerja, Dan Komitmen. Value Added. Majalah ekonomi dan bisnis 8. 
Puspitasari, N. (2010) Hazard Identifikasi Dan Risk Assesment Dalam Upaya Mengurangi Tingkat Risiko Di Bagian Produksi Pt. Bina Guna Kumia Ungaran Semarang. Skripsi.

Putri, A. (2013). Perbandingan Tingkat Kinerja Kesehatan dan Keselamatan Kerja Sebelum dan Sesudah Penerapan Ohsas 18001 di PT. Phapros, Tbk. Jurnal Bisnis STRATEGI 22. 